\title{
On the Road to the Second Century: The Geopolitical Future of the Baltic States in the Visions of Politicians and Political Scientists ${ }^{* * *}$
}

After they had emerged as national republics in 1918, the Baltic states spent the first hundred years of their independence as small, isolated, poorly defended countries that sought to foster their national identity nonetheless. Geopolitically speaking, they had little influence on their environment, rather constituting an area of geopolitical interests of other states. The geopolitical visions of the $21^{\text {st }}$ century picture them as part of an integrated Euro-Atlantic space with good potential to become members of the centre of power that is currently taking shape in Central Europe or provide a strong Western European border next to the weakening Russia. The $21^{\text {st }}$ century will be the age of US leadership, putting the Baltic states, as allies to the US, in a safer position than they were in the last century.

\section{Foreword}

World War I ended in more than just a military victory of one side. The end of the war also brought a global geopolitical shift: a change in the World Order. The imperial regime, which was based on territorial governance, was replaced with one of communal decision. Its product was the so-called national states as a political value. The Lithuanians, too, took the word of creating their own national (or rather ethnic) state, shunning the idea of reconstruction of the Polish-Lithuanian Commonwealth.

That was a triumph of the so-called Woodrow Wilson doctrine. Despite various historical plot twists, states that emerged after World War I have endured for one hundred years. Underrated by geopolitical classicists at first, then

\footnotetext{
${ }^{*}$ Dr. Egidijus Vareikis is a member of the Seimas of the Republic of Lithuania.

Address for correspondence: Gedimino pr. 53, LT-01109 Vilnius, Lithuania. Phone: +370-5-2396606, e-mail: egidijus.vareikis@lrs.lt

** This study was commissioned by the General Jonas Žemaitis Military Academy of Lithuania. Contract nr. 8P-4, 13 November 2017.

${ }^{* * *}$ This study is dedicated to the hundred-year anniversary of the restoration of the State of Lithuania.
}

DOI: 10.2478/lasr-2018-0002 
legalised, they are currently considered geopolitical relics by some, or the best form of self-expression of nations by others.

The purpose of this overview is to take a look at how geopolitical experts predict the second century of the states in our region. Obviously, I will be focusing on the outlook of long-term cooperation between Lithuania and its Baltic neighbours, although I will have to touch upon some regional and even global aspects of the development of the civilisations.

\section{Methods of Future Research and the Opportunities They Offer}

Critiqued as an anachronism decades ago, geopolitics is currently experiencing a renaissance, what with an increasing number of new publications being written and new authority figures emerging. ${ }^{1}$

As often as not, all geopolitical experts love to quote classics such as Mahan, Mackinder, Haushoffer, and so on. Geography definitely has an effect on politics: if our security depends on our geographical proximity to Russia, if our happy neighbours are the Scandinavians, we cannot do without studying the map. According to Robert Kaplan, geography does not forgive those who ignore it. ${ }^{2}$ Yet modern geopolitics greatly trespass the boundaries of the absolute geographical dependence of politics. The economic, historical, cultural, and even emotional dimension is gaining an increasing weight, hence the shift in the attachment to geographical classics. For instance, in a recent study, Phil Kelly attempts to modernise the classical methods with said 'supplements.' Jeremy Black accentuates the significance of history as an act of will that greatly affects the 'objective reality' of geography. ${ }^{4}$ In other words, modern geopolitics is not only about the extent of our geographical dependence, but also the extent of us being able to change the geography in a way that benefits us. The choice of politics is a matter of human decision.

The realists of the policy of security, their opinion currently dominating the ranks of the practitioners as well, understand the world as a chaotic system, where some communities arise and perish, driven by a plethora of circumstances..$^{5}$ In retrospect, it would be easy to explain why the great civilisations

\footnotetext{
${ }^{1}$ Saul Bernard Cohen, Geopolitics. The Geography of International Relations, Rowman \& Littkefield, 2015.

${ }^{2}$ Robert D.Kaplan, The Revenge of Geography, Random House, 2012.

${ }^{3}$ Phil Kelly, Classical Geopolitics: A New Analytical Model, Stanford University Press, 2016.

${ }^{4}$ Jeremy Black, Geopolitics and the Quest for Dominance, Indiana University Press 2016.

${ }^{5}$ Jack Donnelly, Realism and International Relations, Cambridge University Press. 2000.
} 
of the period came into existence between the Tigris and the Euphrates or on the banks of the Nile, why the Portuguese and the Spanish ruled the seas in their own time, and why the Dutch and the British replaced them later on. Predicting what will happen tomorrow or in ten years would be a much more difficult thing to do, because new and unforeseen technological solutions will emerge in the course of history, changing the people's preferences; likewise, we sometimes observe the advent of 'black swans', or unanticipated phenomena that change the situation drastically (such as the Lisbon earthquake in the early $18^{\text {th }}$ century, the tsunami that devastated Japan a few years back, and so on).

Loved by some and critiqued by others, the Theory of World Systems is another concept; an attempt to postulate that global chaos is actually anything but. ${ }^{6}$ There are several determinants (geography included) that allow us to predict today what the future holds for one country or another.

Geopolitical experts rely on the two concepts in their own way. Usually, the World Order is said to be created with good intentions. Yet it is always transient and degenerates with the passage of time. Obviously, there are several key reasons for that.

First, not everyone wants to live by it or recognises it as an appropriate order. Second, not everyone committed to follow the order does so due to a shifting situation. Third, order demoralises those whom it serves. Order becomes disorder that calls for the development of a new order. After the Cold War, the general consensus was that we live in a world where order consists of democracy, market economy, and human rights. Today, we have to admit, more and more often, that this order seems redundant. In other words, the end of history has ended. ${ }^{?}$

This publication has already covered future methods of research; ${ }^{8}$ I will only go through them very briefly.

As it was already mentioned, in addition to geography, there are more objective (conditionally, without a doubt) factors determining the political future of humankind that future planners recognise. Today, said factors include demography, climate change, energy extraction and distribution possibilities, as well as social 'irrationalities', such as religious extremism, celebrity cult, depreciation of the prestige of logic and science - broadly speaking, postmodernism. Not least, we have the dwindling of state power and the shrinking of its

\footnotetext{
${ }^{6}$ Frank Andre Gunder, The World System: Five Hundred Years or Five Thousand?, Routledge, 2006.

7 “The End of the End of History?" in The Hedgehog Review 19 (3) 2017.

${ }^{8}$ Egidijus Vareikis, "World Future Mapping and Scenarios for the $21^{\text {st }}$ century", Lithuanian Annual Strategic Review”, 2014-2015, vol. 13, p. 11-26.
} 
functions, ${ }^{9}$ the negative side of globalisation in the form of international terrorism, organised crime, proliferation of weapons of mass destruction, 'asymmetrical' threats, epidemics, and migration. ${ }^{10}$

Quite a few regularities of the economic-social development of the society that were discovered in the $19^{\text {th }}$ and $20^{\text {th }}$ century allow us to predict, at least to an extent, the development of the community of people. Those worth a mention are the theories of short- and long-term social development cycles, which allow forecasting the 'waves' in economic or social life. Long-term forecasts are concerned with the so-called Kondratiev cycles - long-term waves covering dozens (some 40 to 60) years of economy - where the rises or falls of the economy are followed by wars, upheavals, and so on. ${ }^{11}$

Any future planner attempts to answer several key questions in their possible scenarios. What awaits us as physical and biological beings? What possible future strikes fear in us and what kind of a future would we wish to avoid? Which stereotypes of the civilisation and world order are we prepared to defend, and which to renounce? Are there are any alternatives to our superstitions/stereotypes? Are we strong enough to bring our plans to fruition, do we have the resources? The course of history, as such, is given varied interpretation as well. History may be perceived as a linear, cyclic, sinusoid, or even chaotic process.

Theoreticians and practitioners who design future scenarios usually build them on some pre-conceived scheme. Several typical schemes are worth mentioning. ${ }^{12}$ These are designing a future based on an existing successful model (the so-called used future), building a future by eliminating past mistakes and trying to avoid them in said future (the disowned future), alternative scenarios (alternative futures), scenarios of future alignment that predict a future in an aligned world by stimulating particular, 'useful' tendencies and inhibiting those that are not.

Then there are certain archetypes that allow us to begin writing 'classical' scenarios. One professor of this method, Jim Dator, ${ }^{13}$ has proposed the

\footnotetext{
${ }^{9}$ Peter van Ham, "The Rise of the Brand State: The Postmodern Politics of Image and Reputation", Foreign Affairs 80 (5), 2001, p. 2-6.

${ }^{10}$ Graham Bird, Brock S. Blomberg, Gregory D. Hess, "International Terrorism: Causes, Consequences and Cures", The World Economy, 31 (2), 2008 p. 255-274.

${ }^{11}$ Andrey V. Korotayev, Sergey V. Tsirel, A Spectral Analysis of World GDP Dynamics: Kondratiev Waves, Kuznets Swings, Juglar and Kitchin Cycles in Global Economic Development, and the 2008-2009 Economic Crisis, Structure and Dynamics 4 (1), 2010, p 3-57.

${ }^{12}$ Sohail Inayatullah, "Six pillars: futures thinking for transforming", Foresight, 10 (1), 2008 p. 4-21.

${ }^{13}$ Clement Bezold, Jim Dator's Alternative Futures and the Path to IAF's Aspirational Futures, Journal of Future Studies, November 2009, 14(2), 2009 p. 123-134.
} 
following list of archetypes: the archetypes of growth, disaster, stabilisation, and transformation. ${ }^{14}$

Ergo, the arsenal for future research is vast, yet as was already mentioned, writing scenarios is heavily affected by prejudice and the 'strategic goal' of a client. On the one hand, it is easy to feel that today many answers will bear a mark of the influence from the ideologies that are prevalent here and now; on the other, our physical powers prevent us from predicting that which has never been, meaning that future is merely an extrapolation of the present or past.

\section{The Baltic States in Geopolitics to Date}

The geopolitical situation of the Baltic region, and the states that existed in it, can be appraised in light of classical geopolitical theories. Of course, literature on this subject, especially that written by Lithuanian authors, is scarce. ${ }^{15}$ The mulling of Lithuania's place in the world, and its strategic future outlook, is dominated by sighs over its romantic history, the grand 'from one sea to another' image still woven through it, as well as desperate crying over our tiny little state harmed by everyone. The classical works by K. Pakštas or S. Tarvydas from the inter-war era that geopolitical experts tend to quote the most in their deliberations primarily centre around the case of Lithuania as a small and lonely state. ${ }^{16}$

Within the popular historiography, history of politics has little to say about the way things were in Lithuania prior to the early $13^{\text {th }}$ century. Scanning through historical atlases gives one a weird impression that the territory of the current Baltic states was one of the long-enduring 'white spots' on our continent. The political history of the Baltic states, basically, began with the founding of the cities of Riga or Konigsberg. The outbreak of the $13^{\text {th }}$ century

\footnotetext{
${ }^{14} \mathrm{http} / / /$ www.worldvaluessurvey.org/, accessed on 10/03/2018. To sum it up in more comprehensible terms, under the archetype of growth, for instance, the $21^{\text {st }}$ century has to become the Age of Asia: the levels of production and then, apparently, consumption will be the highest in this region, Asia will decide what the rest of the world should do. A disaster scenario is a surprise epidemic, a tsunami (one has already devastated Japan), some kind of a 'Taliban' or some other thing that will curb the development of economy and wellbeing. This is difficult to plan for, but... Asia stabilising is a Confucius-esque coming to senses, something that has already happened before many times: Asia has never wanted to rule the world... A transformation - something new - possibly Latin America or Central Europe will overshadow Asia's development. Scenarios like that could be designed for other regions as well.

${ }^{15}$ Egidijus Vareikis, "Lietuvos geopolitika - revizijos poreikis", Naujasis židinys - Aidai, Nos 9-10, 2002, p. 444-449; Česlovas Laurinavičius, Egidijus Motieka, Nortautas Statkus, Baltijos valstybiu geopolitikos bruožai. XX amžius, Vilnius: Lietuvos istorijos instituto leidykla, 2005, p. 412.

${ }^{16}$ Stasys Vaitiekūnas, sudar., Lietuvos geopolitika, Vilnius: Mintis 1991, p. 524.
} 
expansion began to shed some light on who those Baltic and Finn-Ugric tribes on the eastern coast of the Baltic Sea were.

Why had a 'white spot' like that endured in Europe for so long? Why did the Baltic coast not produce a renowned state, why was there no merger with the relatively well-organised Russia or Poland made, and why did the Vikings and other strong-willed Christian missionaries of the $13^{\text {th }}$ century bypass those states?

The Grand Duchy of Lithuania was the most typical dry-land state one could find under Mahan's definition. ${ }^{17}$ During the time of Vytautas the Great, both seas were purely a symbol of geographical location, and not some kind of an economic interest. Lithuania managed to completely fail to take advantage of either of the seas: for all practical purposes, the Black Sea was merely a short page in history, while the Palanga-Šventoji strip on the Baltic coast was a symbol rather than an economic interest. The real life in the Grand Duchy and in the Polish-Lithuanian Commonwealth rather took place in the Vilnius-Grodno-Polotsk triangle, leaving Samogitia with the status of provincial autonomy. Lithuania did not have a port of major importance or a navy; the thing they call 'international trade' was an insignificant economic phenomenon. References to significant Hansa centres in Lithuania are way too exaggerated. The formal incorporation of the Lithuanian seacoast to the Courland Governorate in the $19^{\text {th }}$ century did not bring any substantial changes at all. The current Latvia and Estonia (former Livonia) is more of a coastal territory, and even though geographically it is not very suited for navigation and the formation of so-called maritime states, being a province of European maritime states, Livonia became a Scandinavian, rather than Central European, region.

In his reflections on Heartland, a place you need to control if you want to control the world (there have been many maps pinpointing the location of this key place), Halford J. Mackinder ${ }^{18}$ explained how this should be done. All maps depict the Grand Duchy of Lithuania as part of Heartland; what is more, there are maps where Heartland and Vytautas-era Lithuania overlap almost exactly. Therefore, thinking globally, the former Grand Duchy is (or was) a place of extraordinary geopolitical significance. Ergo, one without any actual promise and significance in theory. We could only guess whether the Grand Duchy of Lithuania had failed to grasp its geopolitical chance, or the theory predicting that chance was wrong.

The geopolitical mission that Lithuania or the Polish-Lithuanian Com-

\footnotetext{
${ }^{17}$ Mahan A. T., The influence of Sea Power upon History, 1660-1783, Boston: Little, Brown, 1890.

${ }^{18}$ Harold J. Mackinder, “The Geographical Pivot of History”, The Geographical Journal, London. 1904.
} 
monwealth had pursued for centuries was to offset the ambitions of Russia, another dry-land empire. Russia became a European state with the weakening or disappearance of Lithuania. Ekaterina the $2^{\text {nd }}$ only dared to refer to Russia as a European state when Russia had established itself in the former Livonia, and for all practical purposes, Russia only became part (or a problem?) of Europe after the division of the Commonwealth. By its own definition a state that was both Lithuanian or Belarussian and Russian, the Grand Duchy of Lithuania had refused to hand over to the Duchy of Moscow a monopoly of representing Russians as an ethnos right to the end of its own existence. Past Lithuania failed its geopolitical mission to be Heartland and control the Russians, but perhaps this is a mission it can re-acquire?

After it had been attached to Russia, the entire eastern Baltic coastal region remained a part of it, another typical dry-land empire.

In the German concepts of geopolitical expansion, the Baltic states were part of the eastern expansion and German lebensraum. It is, therefore, completely understandable that the region became the arena of German-Russian wars and deals in the $20^{\text {th }}$ century. With World War I coming to an end, Germany favoured the appearance of independent states on the territory of the former Russian empire, and the Molotov-Ribbentrop pact was an act of a 'peaceful' division of spheres of geopolitical influence.

In the period between the two world wars, the state of Lithuania chose the geopolitical fate of a small continental state. The raison detre of that kind of state could only be its nationality, combining the national factor into a geographical formation. It is, therefore, no wonder that history and geographical ambitions were peppered with national ideas or myths. The need for Vilnius, Klaipeda, or Grodno was usually grounded on arguments of history and culture rather than those of economy, military, or some other persuasion.

It does not come as a surprise, then, that the works by Kazys Pakštas mentioned above are primarily concerned with the geopolitical code of Lithuania as a national state. The way Pakštas understands it, globally speaking, the Lithuanians as a nation live in a relatively dangerous spot, an area of friction of interests. A priori, the geopolitical expert grants Lithuania the status of a small nation. The advice he has for the Lithuanians is rather pessimistic as a result. This geopolitical expert looks into ways a small nation could fight for its survival, and his suggestions are quite desperate indeed. We have to admit that practical geopolitics had prevailed for long decades in the inter-war, Soviet, and even post-Soviet period. The Lithuanians have made peace with the idea that they are a small nation engaged in desperate struggle, an eternal pusho- 
ver to the big neighbours. It is a known fact that Pakštas proposed the idea of Baltoscandia, admitting, however, that it was a desirable, albeit quite unlikely, concept. Prior conditions for Baltoscandia to exist are the absence of absolute threat from the East and complete European guarantees for Baltoscandia's neutrality.

In his article titled 'Lithuania's Geopolitical Situation' (Lith. Geopolitine Lietuvos padetis), Stasys Šalkauskis wrote back ${ }^{19}$ that Lithuania was in the zone of antagonism between the East and West; it wants to be in the West, but has a lot of ties with the East. It is a peripheral state and is destined for neutrality. Stanislovas Tarvydas, in his paper 'Geopolitics' (Lith. Geopolitika), also sees Lithuania in a sad spot amidst great powers, and ponders how Lithuania could become a real and solid bridge between the West and the East. Mackinder's Heartland is sacrificed in favour of the idea of recovering Vilnius in one way or the other, preserving Klaipeda, strengthening the state's unique culture and the nation's intellectual potential, hoping for better times.

After 1918, Central Europe was really a buffer zone between the West and the Soviet Union. The concept of buffer states collapsed after 1945, when the iron curtain fell, dividing both land and the Baltic Sea. It turned out to be the way it is imagined by architects of dry-land empires, a dividing sea. After 1989, when the Soviet Union became weaker but still maintained its military power, the concept of buffer zones somewhat re-emerged. ${ }^{20}$

European Union and NATO expansion brought with it a geopolitical shift. Formerly divided into Western Europe and Central and Eastern Europe, Europe should now be split into Western and Central Europe and Eastern Europe. Lithuania and its other Baltic neighbours would become part of the enlarged Central Europe. By its geopolitical significance and the degree of western integration, today it is what it has been called, and even geopolitically 'murdered', before: Mitteleuropa. ${ }^{21}$ The question is, for how long this geopolitical structure will survive?

\section{The Republic of Lithuania in the $21^{\text {st }}$ Century}

The Republic of Lithuania of 1990 also has its own geopolitical characteristics. A paradox, but today the Lithuanians would find it difficult to identify

\footnotetext{
${ }^{19}$ Stasys Šalkauskis. “Geopolitinė Lietuvos padetis”, Židinys. 1938. N 5-6.

${ }^{20}$ Hardi P., "Security Issues and Nation Building in East-Central Europe" in Weidenfeld W., Jannings J, eds., Europe in Global Change, Gutersloh: Bertelsmann, 1993, p. 201-202.

${ }^{21}$ Timothy Garton Ash. “Does Central Europe Exist?”, New York Review of Books. 1986.
} 
the European region they belong to. If we tried to classify Lithuania as part of Northern Europe, we would see that it is the southernmost Northern European state that, with its Catholic tradition, does not fit into the protestant Scandinavian environment. There are plenty of advocates who would attribute Lithuania to the traditional Central Europe, which would make Lithuania the northernmost border of Central Europe, having little in common with the Habsburg-esque centre of Mitteleuropa. Geographically, Lithuania could also be classed as Eastern Europe, which would place it on a par with countries like Russia, Belarus, or Moldova... but still the easternmost state of Central Europe. Well, then there is a highly 'specific' region - the Baltic states or a Baltoscandia, but it is a matter of politics rather than geopolitics: the Baltic states are nothing but European states that had been occupied by the Soviet Union, while Baltoscandia is a political project that has never been brought to life.

Regions aside, we could say that as of 1990 , Lithuania is like it has never been before: for the first time in history, it has Vilnius and Klaipeda at the same time. Klaipeda is becoming a historically Lithuanian and integrated seaport, while the capital city of Vilnius happens to be in the east of the country. Once designed to serve as a metropolis for Garden, Minsk, Pskov, it is now reduced to a metropolis for Šiauliai, Kaunas, Alytus. This is the kind of Lithuania that integrates in the region where the Baltic Sea becomes an inland body of water - a sea that connects, and not divides.

Obviously, in this type of situation Lithuania finds it very useful to turn towards the Baltic Sea; small wonder then that interests often tend to revolve around Klaipeda, the city becoming a relatively attractive and necessary place. It is a positive sign that actually reflects Lithuania's reorganisation towards the idea of a maritime state.

On the other hand, Vilnius finds itself in a curious position. Vilnius is the capital situated furthest from the sea among the Member States that have access to the sea, ${ }^{22}$ and the third easternmost EU capital after Nicosia and $\mathrm{Bu}-$ charest. ${ }^{23}$ Bearing in mind that historically Lithuania has never been oriented towards the sea, its current re-orientation is a real geopolitical shift. This kind of shift also promotes the state to be more open and not only in a political, but also in an economic and cultural way.

Lithuania is not participating in any consistent discussion about the country's geopolitical future and it is therefore difficult to pinpoint any prevalent national geopolitical idea. As often as not, the current situation is found to

\footnotetext{
${ }^{22}$ By the way, it is Riga's and not Klaipeda's coastline that is the closest to Vilnius.

${ }^{23}$ Not including Cyprus with its specific islandic situation.
} 
be essentially satisfactory to most Lithuanians. Some surveys show that in the opinion of the people, a happy Lithuania should resemble a Scandinavian state (this is the type of Lithuania that the strategy Lithuania 2030 aims to achie$\left.\mathrm{ve}^{24}\right)$; however, this is a political, rather than geopolitical, project.

To sum up the ideas of those who voice their opinions on Lithuania's geopolitics, I can say that there are three stereotypes involved. The first one, I would call ethnic isolationism, the second, Euro-peripheral fatalism, and the third, Euro-Atlantic optimism.

Advocates of the first idea claim that following the restoration of its independence, Lithuania is now a small, weak state surrounded by powers that are stronger just as they are aggressive, and is as much unsecure as it was in the period between the two world wars. We could say that to an extent, this is the characteristic from the end of the last century: Lithuania is a country that falls into the definition of a small state, it has no loyal allies or powerful protectors in a world that seeks economic pragmatism and profit, modestly hoping that it could somehow become a kind of a bridge between the West and the East. The conclusion here is that the fate of the country depends more on circumstances than efforts of the state per se.

Just like Kazys Pakštas once, followers of the idea of ethnic isolationism believe that the reason d'etre of the state of Lithuania is still the strong sense of nationalism. They think that the integration into the European Union is dangerous to the smart sense of nationalism that makes the country so unique. This type of geopolitical thought leaves plenty of room for the mythical unity and romanticised history of the Baltic nations. Another thing wrong with the European Union is its mocking attitude towards the isolationists' utopia of a Lithuania inhabited by extraordinarily clever intellectuals, a state that is free from crime, its economy based on the spirit of national love and ethnic unity.

Obviously, the neutrality of Lithuania as a unique state would be the most logical and reasonable state, yet given the dangerous international situation, NATO integration is a possibility. However, many ethnic isolationists think the integration ought to be a one-sided thing: NATO must defend Lithuania (it is a moral duty of the organisation), whereas Lithuanians would be released from taking part in NATO missions away from Lithuania as it has nothing to do with Lithuania's vital needs. Generally speaking, all major states pursue an aggressive and self-centred policy and therefore should be approached with caution.

Euro-peripheral fatalists are those who believe that isolationism and

${ }^{24} \mathrm{https} / / /$ www.lietuva2030.lt/lt/, accessed on 10/03/2018. 
neutrality would spell doom to Lithuania. Lithuania has to integrate into Western structures, but an integrated Lithuania would eventually become, and remain for a long time, a periphery of the Western world, a doer of Brussel's and Washington's will, although on the other hand the country would have better opportunities for economic development, and security guarantees would boost confidence in the country's potential.

A state like that would still offer no guarantee of Lithuania's security for, as a provincial periphery next to the unpredictable Russia and the dangerous Belarus, the country is doomed to the role of a perpetual straggler and is prone to become the target of some geopolitical exchange. Apologists of the Euro-peripheral way of thinking encourage integration and the fastest possible economic development, they would love to support democratic processes in Russia and Belarus (which would make the situation more secure), look at Ukraine with some hope, considering it a potential geopolitical antagonist to Russia, and willingly participate in the communities of the Baltic states or Baltoscandia. In other words, the fewer geopolitical problems around Lithuania, in its regional code, the better. Recognising the aggression and egoism of the great powers, advocates of the idea in question believe that Lithuania must clearly choose which of the greats are 'homey', and which are 'alien'. Of course, one of the aliens is Russia, while Europe and the US are the homeys.

Advocates of Euro-Atlantic optimism design Lithuania's geopolitics based on a Lithuania that is integrated both in the European Union and NATO. The main thing is that instead of fearing for a geopolitical situation that allegedly poses a security threat, Lithuania should actively participate in solving local issues, becoming an indispensable part of the solution.

Contrary to Euro-peripheral fatalists, optimists believe that the current situation is a chance for Lithuania. The more of a conservative continental state Russia is, the more important Lithuania becomes. Lithuania is not just one of the Baltic states - it is the largest of them all. Lithuania needs to be a member of the European Union and NATO on terms that would make it indispensable both to the Alliance and the Union. Optimists see Lithuania's geopolitical future not as the future of an isolated state, but rather as that of part of the region. Ethnic identity is prone to shift and should not be fostered that much. 


\section{Global and Regional Future Models and the Baltic Region}

The ample literature on future strategies reveal several relatively identifiable, stereotypical political models of the world, or even visions of the future world. They refer to the Baltic region and Lithuania with varying degrees of significance. I will cover some of them here.

It could be that most of the geopolitical forecasts are connected to the American vision of the future, or Pax Americana. The US is the key power in the world, one that defines the entire course of its political development, for all practical purposes. It is a world of continuous struggle for the so-called eternal or fundamental values: freedom, democracy, human rights, and the glue that holds it all together - liberal market economy. The American dream has it that all nations of the world can co-exist together and reach a Fukuyama-esque end of story - the political finale that humankind strives for. ${ }^{25}$ One of the fallacies, according to campaigners for Pax Americana, is the popular belief that the Age of America (and the Age of Europe, too) is coming to an end. Contrary to other authors, the political futurologist George Friedman reminds us that understanding the US's collapse, albeit logical, is still wrong. Before World War Two, the US was not even a super-state and did not even wish to dominate the world. Of course, it became a super-state after World War Two, but instead of dominating, it waged the Cold War with the Soviets. The true Age of America only began with the collapse of the Soviet Empire, which means that it is not the $20^{\text {th }}$, but the $21^{\text {st }}$ century that is due to be the period of US domination. ${ }^{26}$

In the $21^{\text {st }}$ century, the idea of the US ('Make America Great Again') is to thwart the appearance of a major geopolitical dominator to threaten America. Candidate number one here is China or, even worse, a united and integrated Eurasia (an exceptionally successful commonwealth of China, Russia, India, and possibly Indonesia), and so it is in the interests of the US to foil it. In this light, Europe's mission is to be an ally to the US. This is the way it has been so far, and the process needs to go on.

George Friedman delineates clear geopolitical boundaries of Europe, claiming Europe to be a peninsula that starts to the west of the St PetersburgRostov-on-Don line (Fig. 1). The line clearly shows that the Baltic states, Belarus, and Ukraine are part of Europe, while Russia and Moscow are already outside of the peninsula. As a result, making this line the true boundary between civilisations is the strategic objective of the $21^{\text {st }}$ century (or at least its first half).

\footnotetext{
${ }^{25}$ Francis, Fukuyama, The End of History and the Last Man, Free press, 1992, 418 p.

${ }^{26}$ George, Friedman, The Next 100 years: A Forecast for the $21^{\text {st }}$ Century, Anchor Books, 2009, $254 \mathrm{p}$.
} 


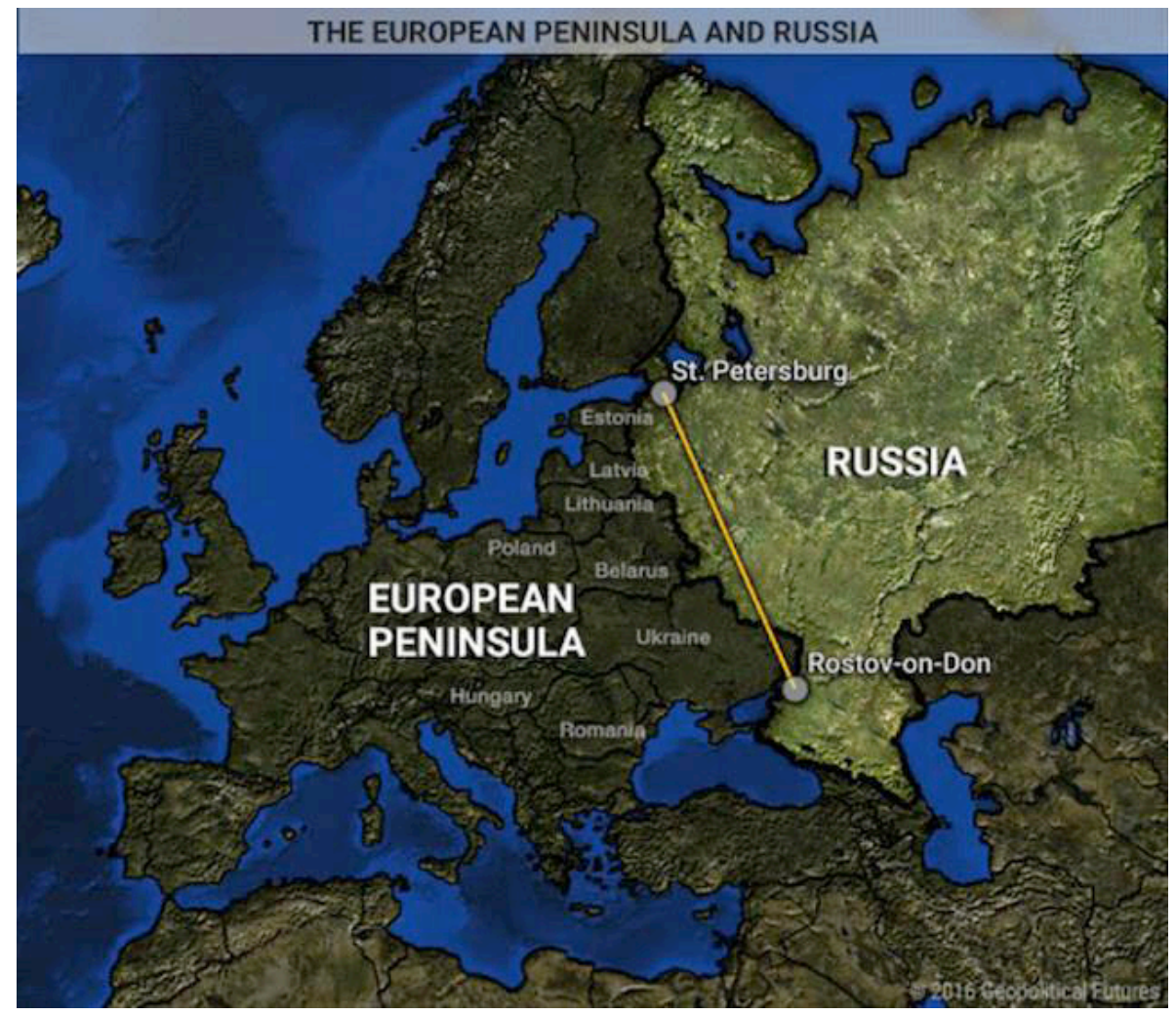

Figure 1. The European Peninsula and Russia, a map by the Geopolitical Futures portal ${ }^{27}$

It is completely obvious that according to this vision, Lithuania stays part of the 'real' Europe. The continued weakening of Russia under this vision is inevitable. The entire gargantuan Russia, with its 140 million inhabitants, is becoming an increasingly less imposing power compared to the integrated Central Europe, from Finland to the Black Sea and the Adriatic Sea, its population totalling, as near as makes no difference, 100 million. It is the strengthening of Central, and not Western Europe that is in the geopolitical interests of the US, and George Friedman predicts that the new regional centre of power could become what he refers to as 'New Poland' (personally, I would rather call it the New Polish-Lithuanian Commonwealth). In this respect, Lithuania is in for a quite optimistic and even geopolitically responsible future.

\footnotetext{
${ }^{27}$ George Friedman claims that geopolitically, Europe is the Eurasian Peninsula stretching to the west of the line drawn on the map. The Baltic states, Belarus, Ukraine are European countries, while Russia is outside of Europe. Fixing that line would mean a kind of reclaiming Europe from Russia's influence.
} 
Western Europe, with all of the EU structures, is poised to grow weaker. As a result, amidst the weakening Russia and Western Europe, it is Central Europe that will become a new centre of power. The 'New Poland', a US ally, will be the geopolitical formation that will play an important role in the global politics of the $21^{\text {st }}$ century.

Another geopolitical guru, the recently deceased Zbigniew Brzezinski, believed that Russia can be successfully checked when a powerful alternative to Russia arises in the region. This country should understand that it is not built to last, and a contender may come one day to claim its geography and resources and to disallow it to impose its dictate on its geopolitical neighbours. ${ }^{28}$ Brzezinski thought that an integrated Europe and NATO drawing closer to Moscow and Russia becoming weaker is an inevitability. This then will strengthen the Baltic region's position as part of Europe and will remove it further and further away from Russia.

It is worth remembering that when he wrote about collisions of civilisations, Samuel Huntington, too, 'envisaged' a place for the Baltic region in the Western European civilisation. ${ }^{29}$ Which makes the ideas of this leading geopolitical figure quite favourable to us.

Visions of the short-term future prevail in Europe, most definitely due to the EU influence. In other words, what will happen to the European Union. They are not talking about any kind of a major change, be it new large-scale expansion or the Union's collapse. The latest suggestions from the most recent period are the so-called Junker scenarios..$^{30}$ As we know, they refer to potential reformation of the EU as a long-term vision, even though this is more of a tool to address the present crisis rather than one to engage in some strategic creative work. When it comes to us, it is relevant to the extent that Lithuania and its Baltic neighbours are anchored firmly as an unquestionable part of integrated Europe, an undeniable territory of its vital interests.

Still, there are talks in Europe about Europe's future after the European Union. Swedish historian Gunnar Wetterberg, for one, suggests reviving the Kalmar Union, an old Scandinavian integration that now only historians remember. ${ }^{31}$ In the $14^{\text {th }}-16^{\text {th }}$ century, the Nordic countries, nominally under the rule of a single monarch, enjoyed a sufficient degree of sovereignty and

\footnotetext{
${ }^{28}$ Brzezinski Zbigniew, The Grand Chessboard: American Primacy and Its Geostrategic Imperative, New York: Basic Books, 1997, 223 p.

${ }^{29}$ Huntington Samuel, Clash of Civilizations and the Remaking of World Order, Touchstone, NY, 1997, p. 368 .

${ }^{30} \mathrm{http}: / /$ europa.eu/rapid/press-release_IP-17-385_en.htm, accessed on 02/01/2018.

${ }^{31} \mathrm{https} / / /$ euobserver.com/opinion/31188, accessed on 02/01/2018.
} 
were quite rational in their management of the union's and national interests. If today, the Nordic countries (including all of their islands, such as Iceland and Greenland, as well as the Baltics) joined to make a single formation, they would cover an impressive area of 3.5 million sq. $m$ (an area to overshadow India) and would have a population of some 26 million. Most importantly, they would be the eighth largest economy in the world, an economy that would exist at a safe distance from all the wars and disturbances. This could also be a union for the Dutch and even the Belgian Flemish, who are now sick and tired of the Belgian kingdom. This would put it in a position to negotiate with the British, and even with America, on equal terms. Another thing that makes this outlook so appealing is that Lithuania grounded its future vision (the Lithuania 2030 strategy) on the postulate that the Lithuanians would be happy if they were more like the Scandinavian nations. ${ }^{32}$

Another potential prospect of European integration is New Switzerland. This country, which once united, as if in a pinch, Europeans who spoke different languages and practiced different religions, did not descend into wars but, rather pragmatically, created a heaven on earth instead. Member to no economic or military union, the country is still a global leader in terms of innovation, competitiveness, and other aspects that benefit the economy. The influential Italian Northern League is already making suggestions that they should stop 'feeding' the backward, albeit Italian-speaking, South and think about establishing a new type of alliance with the Swiss, southwestern German, and perhaps Belgium instead. Slovenia could join as well. We are not here, and if New Switzerland (or possible the New Holy Roman Empire) is to expand, we could find ourselves somewhere in its periphery.

Many political observers note that geography and economy are not the only factors that drive the establishment of political alliances. With Central Europe, the biggest political problem is the fear of Russia. It could be resolved with the New Polish-Lithuanian Commonwealth covering the Baltic states, Poland, Belarus, and Ukraine. A sea-to-sea territory, population: 110 million. The Intermarium, to which we belong, is becoming an increasingly trending thing in political debates. ${ }^{33}$ According to Zbigniew Brzezinski, this too would force Russia to review its potential for expansion. The Roman Empire once split into the West and the East. After all, there are many who currently believe that the period was a 'golden age' for the Lithuanians, the Poles, and a lot of western and central Slavic nations.

\footnotetext{
${ }^{32} \mathrm{https} / / /$ www.lietuva2030.lt/lt/, accessed on 02/01/2018.

${ }^{33} \mathrm{https} / /$ geopoliticalfutures.com/intermarium-three-seas/, accessed on 02/01/2018.
} 
The Chinese vision involves economic development leading to employment, a source of subsistence and wealth for everyone willing. It is no secret that recently there have been plenty of forecasts favouring China: they say that China is the future ruler of the world and we can but prepare for this historical fact. ${ }^{34}$ Formally, the Chinese dream looks very beautiful: after all, China is a peaceful state that, following the Confucius idea, does not wish to conquer anybody. On the contrary, it strives for harmony where both China, as the Middle state, and the world that surrounds it would be happy.

According to the Chinese vision, we are the edge of the world, a spot that holds little interest for now. Of course, all the better for us - we can begin painting a 'golden future' for ourselves. Quite a few political experts say that China is in for an impending crisis, very similar to the collapse of the USSR, so that the long-term forecasts of Chinese development and the global implications thereof should be approached with caution.

Over the past two decades, none of Russia's geopolitical projects or dreams have come true. The greatest dream - restoring the status of a great power (and the geographical boundaries of the USSR) still remains hidden between the lines. Russia is just not strong enough for that. The country has no charming messianic idea. Russia is inflexible in its ideology. Imperialism today is a luxury one can hardly afford, but Russia cannot imagine itself without it. It is hostage to its imperialist nature and finds it extremely difficult to change its own views, however harmful they may be. It is like an addiction - an addiction to imperialistic thinking that is turning into geopolitical kleptomania. For now, it is rather inclined to hide its afflictions, instead of getting treatment. Russia basically has two choices: an authoritarian regime with an aggressive foreign policy, or an upheaval which may destroy Russia as we know it.

Current Russia was created through ham-fisted geographical expansion by simply overpowering neighbours and imposing its political will on them. It is therefore natural that its entire geographical perimeter is permeated with grievance, fear, or even a desire for revenge. Russia in fact does not have any friends in its neighbourhood; all the friendly states are so not because they find Russia attractive but because they are either bound by economic or mercantile interests, or faced with even worse. To be able to expand or to survive today, Russia has to fight (politically, and eventually physically as well) on several fronts, which is not an easy thing to do. What is worse, Russia's neighbours

\footnotetext{
${ }^{34}$ Ikenberry G. John, "The Rise of China and the Future of the West. Can the Liberal System Survive?", Foreign Affairs, 2008. Žiūrèta https://www.foreignaffairs.com/articles/asia/2008-01-01/rise-china-and-future-west, 2018.03.10.
} 
manage to unite against Russia, something that has never happened before. There are no guarantees of Russia's own internal stability.

Of course, being further away from Russia in the event of an upheaval benefits us, yet its expansive convulsions are dangerous. The concept of Russia as a Eurasian state is developed by Alexander Dugin, one of the country's most prominent geopolitical experts.

Dugin's Eurasianism is named after Russia's post-Soviet policy of imperialism. ${ }^{35}$ Its biggest threat, according to Francoise Thom, a prominent observer, is that Russia's 'true and legitimate' borders are not and have never been demarcated. ${ }^{36}$ Dugin's Eurasia is the territory between Dublin and Vladivostok, which includes us, obviously. We are in the zone of Russia's expansionist interests.

From the point of view of classical geopolitics, Dugin can see a conflict between Atlanticism (the ambitions of the US and Great Britain) and Eurasianism, with Russia as its key component ${ }^{37}$. The American democracy and statements about human rights are also the soft power of the West that could destroy Russia. Russia is a unique civilisation in its own right, with the messianic power to melt nations not in Russia's ethnicity, but in its spirit of a great state, which is both messianic orthodox and Eurasian (and not necessarily Slavic). Gorbachev's and Yeltsin's projects of westernising Russia were a complete fiasco. It was a failed conspiracy of Atlanticism against Russia, against the Heartland that Russia constitutes. Today's Russia is not a product, but an intermediate formation that needs to be developed to become a Eurasian empire.

In Dugin's words, Russia's policy has to rely on three axis: Moscow-Berlin, Moscow-Tehran, and Moscow-Tokyo. Obviously, we are concerned the most with the first one, which is based on cooperation between Russia and Germany that could, de facto, lead to some new Molotov-Ribbentrop pact. Central Europe may temporarily be Germany's 'protégé, or its countries might enjoy a 'special' status in the sphere of Russia's interests. He believes that Estonia could be more German, while Lithuania, Latvia, and Poland, more Russian. Belarus has to become a part of Russia. Ukraine has no geopolitical value whatsoever. Most its territory is Russia, and only its western part could spawn a separate state.

\footnotetext{
${ }^{35}$ Aleksandr Dugin, Osnovy geopolitiki: Geopoliticheskoe budushchee Rossii; Myslit' prostranstom Moscow: Arktogeya, 1999, 925 pp.

${ }^{36}$ Francoise Thom, Eurasianism: A New Russian Foreign Policy? Uncaptive Minds, 7 (2), 1994, p. 76.

${ }^{37}$ For a useful survey of the twentieth century Western geopolitical literature, see Geoffrey Parker, Western Geopolitical Thought in the Twentieth Century, London: Croom Helm, 1985. Chapter five of Parker's book is devoted to "German Geopolitik"
} 
From the standpoint of classical geopolitics, both German and Russia are dry-land empires that address their problems by dividing the neighbouring territories between themselves. Karl Haushofer, one of the most prominent German geopolitical experts of the $20^{\text {th }}$ century and, allegedly, Hitler's number one adviser, claimed in his texts that Germany is a dynamic dry-land state that has been 'enclosed' unsuccessfully amidst the neighbouring states. For Germany to become stronger, or even for Germans to rule the world, an alliance with Russia, another dry-land state, would need to be made first, and then a war would have to be waged with the European maritime states, Great Britain included, to gain a strong foothold in Europe. This would be followed by war against the US, and eventually, when everyone is already out of the way, there would be war against... Russia itself.

In the words of said geopolitical expert, some dry-land empires (such as Germany) grow under the principle of metastasis: they take hold of strategically important points and turn them into new centres for their expansion. That was the way the Germans penetrated deeper into the Baltic region by occupying Klaipeda, that was the way they operated in Silesia and elsewhere. Other dry-land empires spread under the wave principle, by gradually 'swallowing' neighbouring territories. That is what Russia is like. The logic behind its expansion is to spread in all directions away from the centre, in all directions from one ocean to another. Russia's nature shows the empire's ambition to have the shortest possible dry-land borders so as to need to fortify a shorter defence line against its potential adversaries.

Central Europe's biggest bottleneck is between Rostock in former Eastern Germany and Trieste in Italy, near the Adrian Sea. It is just $860 \mathrm{~km}$ long. It mirrors the boundary that separated the spheres of interests of the East and the West during the Cold War almost exactly (Fig. 2). In 1945, in the name of the USSR, Russia reached one of the most convenient borders in the history of its expansion. 


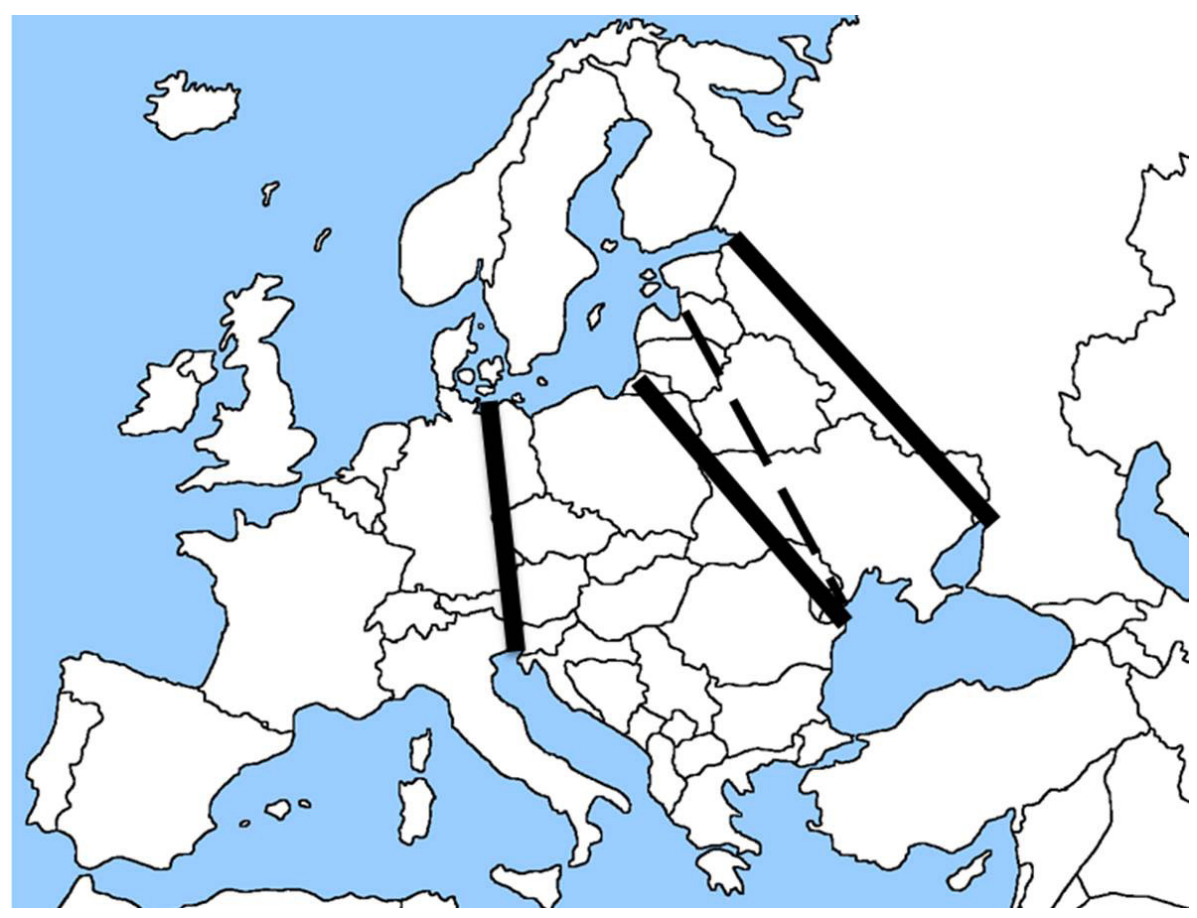

Figure 2. Europe's 'bottlenecks'38

The shortest distance between the Baltic Sea and the Black Sea appears to be the line connecting Konigsberg and Odessa and matching the western border of the former USSR fairly well. These 1,180 kilometres are the second line of the Russian empire already, a territory Moscow's ideologists used to consider their own. Geopolitically, Finland should be considered part of Russia as well (there are politicians in Russia who believe just that). The bottleneck in Scandinavia mirrors the current border between Finland and Sweden, and the former border between the Russian Empire and the Kingdom of Sweden. As we go further, we can see that the line between St Petersburg and Rostovon-Don $(1,500 \mathrm{~km})$ separates Russia both from the Baltic states and Belarus and Ukraine perfectly. Could this be Russia's third line of 'defence'?

Every deviation from the above short borders is a problem of the imperial strategy to Russia. If we take a look at the maps of Europe and the former USSR, we will see right away that one of the inconvenient borders runs betwe-

\footnotetext{
${ }^{38}$ Europe's 'bottlenecks' match the Russian/USSR expansion and its spheres of influence. Rostock-Trieste $(860 \mathrm{~km})$, Konigsberg-Odessa $(1,180 \mathrm{~km})$, St Petersburg-Rostov-on-Don (1,500 km). The dotted line shows the Molotov-Ribbentrop line between Riga and Odessa.
} 
en Finland and Russia. Another 'inconvenient' Russian border rises when Belarus and Ukraine remain in the sphere of Russia's interests, while the Baltic states become independent. Our eastern borders with Russia and Belarus now look like the border between Russia and Finland. And it is in Russia's interests to make it 'shorter'.

Against the background of the Russia-Germany negotiations, what matters to us most is that at just $1,260 \mathrm{~km}$, the Riga-Odessa line is not that much longer than the Konigsberg-Odessa line. It is a known fact that under the 1939 Molotov-Ribbentrop pact, Latvia and Estonia remained in the sphere of the USSR's interests. Which is almost an exact match to the Riga-Odessa line. By the way, after World War I, the line dividing the spheres of interest of two dry-land empires, Germany and Russia, ran along the River Daugava. This is where the genesis and essence of the pact lies.

How much significance does this hold now, when Germany does not have a new Haushoffer and formally has no plans to conquer any new territories, and Russia is too weak to engage in a new division of Europe? Russia's history of the past few centuries shows that the country has won several major geopolitical victories just as it has suffered several grievous failures. In the $18^{\text {th }}$ century, it overpowered Sweden - a strategic victory - and in the $19^{\text {th }}$ century, Napoleon; in the $20^{\text {th }}$ century the country triumphed over Hitler, its geopolitical ally. On the other hand, it lost the Crimea War in the mid- $19^{\text {th }}$ century, thus almost ending its expansion to the south of Europe, and suffered a fiasco in the war against Japan in the early $20^{\text {th }}$ century, becoming the first European state to lose to Asia in modern times. It also lost World War I, and the Cold War as well, which has shaped Russia the way it is now: a geographical mammoth and economic weakling, a state with its own arsenal of nuclear weapons. Russia should choose between Europe and Asia and go for Europe, but it is not inclined that way yet. This is what Dmitri Trenin ${ }^{39}$ says, and he is completely right. He believes that the Baltic states are not part of Russia, and no plans should be laid for a second invasion. However, this concept is not as popular in Russia as Dugin's ideas.

The libraries of geopolitical scenarios are teeming with ideas like the New Caliphate (the Islamic vision), an Orwell-esque global dictatorship, a post-American multipolar world, and so on, which however bear no particular reference to Lithuania and its neighbours. The only thing worth mentioning is the so-called BRICS scenario that designates Brazil, Russia, India, China, and

\footnotetext{
${ }^{39}$ Dmitri V. Trenin, The End of Eurasia: Russia on the Border Between Geopolitics and Globalization, 2002, 354 p.
} 
South Africa as the key poles of the world in the future ${ }^{40}$; its authors, however, draw no maps, resorting to painting visions of economic integration instead.

Finally, we still have the Black Swans, something that cannot be predicted, a complete surprise, like has happened before in the course of history.

Yet today we live in a time when we have the power to decide, like never before, which geopolitical aspect suits us the most.

\section{Conclusion}

During the first century of the Republic of Lithuania, the country's geopolitics was grounded on the policy of Lithuania as a lonely, isolated community that is surrounded by enemies. As a result, Lithuania would not dictate its ambitions to the neighbouring states, but rather became an object of their political deals.

The $21^{\text {st }}$-century Lithuania can be seen in geopolitical predictions as part of a larger region, its fate tied to the needs and ambitions of the surrounding countries as well as global political processes.

Many prognostic scenarios picture Lithuania and its Baltic neighbours as an unquestionable part of Western Europe and the Euro-Atlantic civilisation with its future depending on the outcome of the entire civilisation.

The only country to question the Euro-Atlantic future of the region is Russia, which predicts a division of Europe after the Molotov-Ribbentrop fashion with the Baltic states falling into the sphere of Russia's influence.

January 2018

${ }^{40} \mathrm{http}: / /$ www.bricsforum.org/, accessed on 10/03/2018. 